Journal of

Philosophy, Culture and

Religion

(JPCR)

Oral Theology: an alternative theological model for African Theology

Chesosi Bonface Kimutai

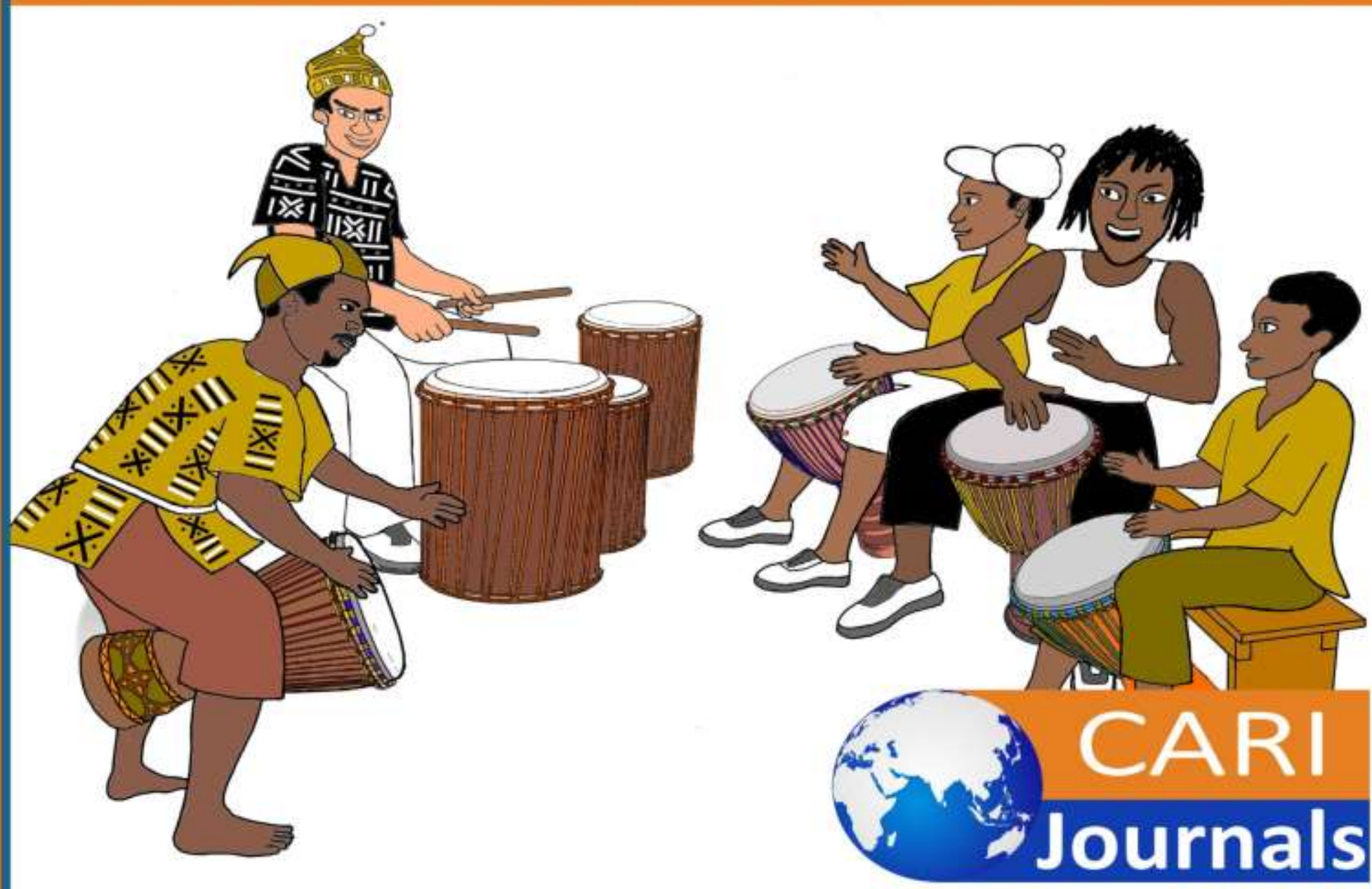




\title{
Oral Theology: an alternative theological model for African Theology

\author{
${ }^{1 *}$ Chesosi Bonface Kimutai \\ ${ }^{1}$ Post graduate student: Africa International university \\ *Corresponding Authors Email: chesosi2015@gmail.com
}

\begin{abstract}
Purpose: The crux of this paper is to explore the rationale and basis of doing oral theology in the African context and situation. It debunks the myth that written theology is the only viable modus operandi of doing African theology.

Methodology: The study using the desktop research methodology or library research establishes the vitality and significance of oral theology in the quest for authentic African theology which adheres to Biblical fidelity and cultural relevance.

Results: The challenges of Oral Theology can be mitigated by importing written form of theology to capture the Oral Theology without minimizing or obfuscating its distinctiveness of Oral Theology. It can also be stored in for posterity so that it is not lost. We can also integrate Oral Theology with narrative theology to formulate, promulgate, define, defend and document an oral Theology that has the narrative at its trust. Oral Theology cannot be a standalone Theology. It needs to be buttressed with written Theology to preserve it for posterity. It also needs to be integrated to systematic Theology to make it intelligible relevant and appropriate to the African context and situation. Oral Theology needs to be formulated in a sense that it should supplement rates than supplant Bible hermeneutics story telling should not viewed as a surrogate to Biblical exposition of the text.
\end{abstract}

Unique contribution to theory, practice and policy: The study recommends an integrated theological method that synergizes oral theology with written theology for African theology to have both biblical fidelity and cultural relevance. Oral theology ought to be included in the church teaching curriculum especially in its theological education by extension which is an informal theological education targeting church ministers. This will go a long way in enhancing the quality of church ministers and will lead eventually to exponential church growth.

Keywords: Oral Theology, African Theology Written Theology, Systematic Theology and Western theology.

\subsection{INTRODUTION}

The conventional presupposition in theological academia is that theology is the study with particular suppositions, organized in a particular manner and exclusively based on writing and reading. This conventional theology is prevalent in African Theological institutions that regurgitate western oriented theology of Millard J. Erickson, Wayne Grudem, and Louis Berkhof as the classic and typical text books of systematic theology. 
It goes without say that the theological presentations in these books are orthodox. However, the subject matter is not relevant to the African life and situation. Secondly, conventional systematic theology is formal with literacy as prerequisite. As a result, it excludes the unschooled and the illiterates. This becomes an elite enterprise and the preserve of the learned. Africans are intrinsically and intensely oral in their culture and worldview. As a result, stories and other oral presentations are how they express themselves, in their thoughts and actions.

The three above mentioned situation necessitates that there is need to formulate a theology that is relevant to the African context and situation; - a system of theology that will incorporate the unlettered Christians. This is by expressing the theology in the oral form with a narrative focus. This endeavor is only tenable and feasible in conceptualizing an African theology that is relevant, practical and compatible to African world view with an oral focus. According to Anthony Simmons in the journal of African theology and black theology part 1, the term African theology has its roots in the 1950s momentous theological discussions in Rome that evolved African and Haitian priests deliberating on how to integrate indigenous traditional African beliefs, rituals, history and culture into the authentic Christian message of Christ for the people (Simons, 2017).

Prof John Samuel Mbiti aptly defines African theology as "the theological reflection and expression by African Christians" Professor Mbiti trichotovcccmizes the three distinct expression of African Theology as written theology, oral theology and symbolic theology (Nairobi,Kenya: OUP, 1986).. He elucidates the distinction by stating the written theology is a preserve of the privileged few who have the education and are adapt in promulgating their theology in books and journals. While oral theology is produced by the nature of the Christians in African in forms of songs, sermons, teachings, prayers, conversations etc. it is a theology in the open-air transmitted oral to either a large or a small congregation. It is mostly unrecorded and therefore may not find itself in libraries and seminaries. (Mbiti, 1979) John Mbiti in identifies the two presentations as the basis for the present trends in African theology.

The symbolic theology finds its epitome in fine art, sculpture, drama, symbols, rituals, dance, and numbers etc. This could be visualized oral theology that is replicated in various worship shrines in the African Traditional Religion and has found its place in the Christian church especially the Roman Catholic Church and it is a genuine expression of theology.

In all these presentations we find the expression of African theology while written theology excludes the illiterate. Symbolic theory may be a bit abstract to those without affinity to it. The truth is that the oral manifestation may be the most widely used medium of theologizing in Africa. As a result, in this study the definition, essence and the challenges of doing oral theology in Africa with proposed remedies to mitigate the challenges will be explored. The study of oral theology finds its relevancy in the African context.

\subsection{Statement of the problem}

The overemphasis on written theology in Africa theological academic is not corresponding to the reality in the African context and situations that is thoroughly oral in orientation. Consequently, there is a need to address this lacuna by formulating a theology that will bridge one gap and conceptualize a theology that the African will be at "home" with it. This oral 
International Journal of Culture and Religious Studies

Vol.1, Issue No.1, pp 1 - 7, 2020

WwW.carijournals.org

theology must of necessity supplement and not supplant or written theology so that we can have. a theology with a biblical fidelity and relevance to the African context and situation.

\subsection{METHODOLOGY}

The study adopted a desktop literature review method (desk study). This involved an in-depth review of studies related to Oral Theology. Three sorting stages were implemented on the subject under study that is dual practice in order to determine the viability of the subject for research. After an in-depth search into the top key word: Oral theology, African Christian theology written theology, systematic theology and western theology.

\subsection{FINDINGS OF THE STUDY}

\subsection{Oral Theology and its Implications}

The Christian church must of necessity have four distinct marks. She must be self-governing, self-supporting, self-propagating and self-theologizing. Then if the church is self-theologizing then it is true that theologizing is the enterprise of the whole church or a part of the church? This is question that we will be pondering circumspective as we vet the Oral Theology. Any term without apt an acute definition may be prone to misconceptions. Oral theology is not an exception in this maxim. Oral theology is unlike systematic theology that is organized in a manner based on a particular topic like soteriology anthropology, ecclesiology, eschatology etc. According to Piet Naude oral theology refers to, 'the varied religious expressions of an oral community based on their underlying religious expressions.' (Naude, 1996,22). Whereas systematic theology is abstract, narrative theology is practical. While systematic theology is written, oral theology is verbalized. Systematic theology is preserved in books and oral theology is preserved in memory.

It is imperative at this juncture to identify sub tent features of oral theology in African context. According to Anthony Casey in his insightful paper on the use and limitation of oral tradition in the New Testament and the implication for theology in oral context, oral theology is firstly contextual. (Casey:2017) It is an acknowledgement that oral societies like Africans receive translate and transmit scripture in their interpretation and application of scripture. This is despite the formal and written education. They interpreted reality orally. Hence a completely written theology will not totally impact the African and will be impotent inn penetrating the African world view. This indicates the need for oral theology.

Oral theology is secondly valued in Africa because it is personal, memorized and in oral communication. It is existential in the sense that is focused on the individual appropriation and application of scripture. Hence it debunks myth at theology is a preserve of the theologians in the theological school. It appreciates individual interpretation and perspective of scripture. It's also not exclusively based on writing and book but on memory which makes the entire church to be the custodian and vanguard of the theology. It is also verbalized hence it makes every Christian a theologian and theology because an enterprise of the whole church especially in the oral culture of Africa. 
Thirdly, oral theology is an emic theology which is determined by local custom, meaning and belief and not etic which attempts to be cultural neutral and alienates any cultural predisposition like systematic theology which purports to be culturally neutral yet it is conceived and promulgated from a typical western mindset.

Fourthly, oral theology is a reflection of theology in progress. Even in the New Testament treatise which was written especially the gospel based on oral tradition. Then from the written gospels, Oral theology vindicates not the absence of theology but the evidence of theology at its infancy and growth awaiting its maturity. Is Professor Mbiti succinctly captures this truth in the illuminating title of his article "cattle are born with ears; their horns grow later "towards an appreciation of African oral theology. (Mbiti:1979,1). We deduce the fact that oral theology is a theology in progress to its full elucidation formulation. We can confidently state that Oral Theology is a work of Oral Theology should be bettered improved and completed rather than to be lambasted and condemned for it is a work in progress theology.

The fifth characteristic of oral tradition is that in its part in the creation of the gospel attests to its trustworthy. As Anthony Casey states categorically that 'evangelical scholars are convinced that oral traditions were accurately recorded in the gospel and the tradition itself was not significantly altered prior the recording.' This affirms to the reliability of oral tradition contrary to the assertions of the liberals and other scholars.

The sixth mark of oral theology is that it has several distinct sources. The Lomwe of Africa houses their theology in their songs not in written texts. Stuart Foster in his book- Oral Theology in Lomwe songs vindicates this position 'that many ordinary Christians whose reflections on the gospel can be discerned in their prayers, songs, testimonies, thanks offertory and sermons. (Stuat:2008,130). Prof. Mbiti identifies the main sources of oral theology and expands the sources to include; evangelization, conversion, sermons and preaching, hymns and songs, praying and conversations (Mbiti:1979).

The seventh mark of oral theology is that it thrives in face to face encounter and not on written texts. Oral theology relies on face to face contact those involved in the interpretation and application process. Hence its values text and testimony. Consequent oral theology is better suited in the church context unlike systematic theology which is suited for the library and in term papers. The eighth mark is that oral theology is based on stories not philosophical elucidation to expound the truth which is more relevant and authentic in the African situation.

According to Bruce C Salmon in his Classic Masterpiece story telling in preaching aptly observes that "stories can help to bridge the distance between the world view of the Bible and our own". (Salmon:1988,132). This implies that stories as captured in oral Theology is useful in vivifying and classifying the Biblical world to our contemporary audience. As a result, Oral Theology is very useful in elaborating and classifying the Biblical message. It makes the message alive and interesting unlike it being wooden with factual presentation of systematic Theology. The truth is further affirmed by Michael Phillippart in the book The African church in the communication era where he states that "in communication at church levels and within church institutions make deliberate attempt is focus on the oral and traditional media for effective use of storytelling asserts that oral theology and its medium of storytelling is an effective way of 
communication to make the message intelligent, relevant and appropriate." (Phillippart, 1992,112).

The ninth mark of oral theology is that it is limited and has pitfalls in that different tradition of first the Oral theology may arise which may potentially lead to heresy. Secondly there is no fixed text to go back for authority when the Oral Theology tradition conflict. Thirdly the oral testimony is exalted in the sense that the Bible is used as a charm or a fetish to accelerate prayer and healing rituals but they don't open to read or hear it in any kind in the oral form. Fourthly the bible can be taken out of context and used allegorically to fit the whims and agenda of oral interpreter. Fifthly oral theology cannot be sustained in a long theological argument and discourse. Sixthly the Oral Theology is confined and limited to a particular group and may not be theologically scrutinized by rigorous of intellectual scholars. It is difficult to transfer oral theology from one culture to another.

Tenth Oral Theology is a genuine creation of African Christians but can be improved by first avoiding its inherent pitfalls and it suggests how to mitigate by formulating it into a hermeneutical system that can be used in making the bible more intelligible to the Africans as in narrative theology that interprets the bible with the story focus and uses African forms riddles stories to explain the biblical message. It makes the biblical message to be more vivid, practical and lively preaching, reading, conversation unlike the exposition of systematic theology.

\subsection{CONCLUSIONS AND RECOMMENDATIONS}

\subsection{Conclusions}

The challenges of Oral Theology can be mitigated by importing written form of theology to capture the Oral Theology without minimizing or obfuscating its distinctiveness of Oral Theology. It can also be stored in for posterity so that it is not lost. We can also integrate Oral Theology with narrative theology to formulate, promulgate, define, defend and document an oral Theology that has the narrative at its trust.

Oral Theology cannot be a standalone Theology. It needs to be buttressed with written Theology to preserve it for posterity. It also needs to be integrated to systematic Theology to make it intelligible relevant and appropriate to the African context and situation. Oral Theology needs to be incorporate into the church catechism and doctrine lesson. In the contemporary generation and society that is postmodern that shuns metanarratives and is so oral and audio and does not derive pleasure in the intellectual enterprise. Hence the conventional written system Theology may not be able to cite the contemporary need unless it is integrated with oral Theology.

Oral Theology needs to be formulated in a sense that it should supplement rates than supplant Bible hermeneutics story telling should not viewed as a surrogate to Biblical exposition of the text. It is sometimes taken out of proportion and is supposed to replace homiletics, exegesis and hermeneutics. Oral Theology should be a methodology of conceptualizing theology in a way that is comprehensible and intelligible to the ears but should not seek to replace exegesis, homiletics and hermeneutics. Oral Theology should be incorporated in our Christian orthodoxy and practice. From this study, it can be used as a lens for me to be make comprehend more systematic Theology. The study has made a conscious effort to ensure that oral Theology is appropriated in 
homiletics and teaching without allegorizing and losing the original meaning of scripture. Oral Theology needs to be incorporated to the African Theology. As a result, the study affirms that oral theology is the evidence and authentication of African Christian Theology that is prevalent in Africa. Truly Oral theology cannot be ignored, obliterated or downplayed for it an integral and undisputable part of African theology if it has to be relevant, authentic and practical. This is buttressed with the eloquent words of John Pobee who candidly affirms that:

It is often asserted that Churches in Africa have no theology. When one probes what is meant by this remark is that they have not produced theological treaties and tomes systematically worked out in volumes which stand on the shelves of libraries. But it is not exactly true. Sermons are being preached every Sunday which are not subsequently printed. Such sermons are the articulation of faith in response to particular hopes and fears of people of Africa. They are legitimately called theology, oral theology. This oral theology and oral history may be said to be the steams in which the vitality of the people in Africa, illiterate and literate is mediated. As such the material cannot be ignored. (Pobee:1989,89).

In conclusion oral theology can be integrated into the African theology to make it accessible to the entire Christian community in Africa. Oral theology will be a bridge between the intellectual theology that is found in theological academia and practical theology that is peddled in the streets, in the pulpit, and other informal places. Oral theology will make intellectual theology reach then illiterate Christians because it will be verbalized and it will impact practical theology and make it genuinely Christian. Consequently, we have no choice but to embrace oral theology as an alternative theological model for doing African theology.

\subsection{Recommendations}

The study recommends that oral theology be considered as an integral part of African Christian theology for it should supplement rather than supplant the conventional written theology. Oral theology can also be utilized as a Modus Operandi or a teaching methodology to educate African church ministers without formal education and this will go a long way in demystifying elitist theology that is a preserve of the schooled or the lettered people. The study recommends an integrated theological method that synergizes oral theology with written theology for African theology to have both biblical fidelity and cultural relevance. Oral theology ought to be included in the church teaching curriculum especially in its theological education by extension which is an informal theological education targeting church ministers. This will go a long way in enhancing the quality of church ministers and will lead eventually to exponential church growth.

\section{REFERENCES}

Casey,Antony.(2017) The use and Limitations of the Oral Tradition in the New Testament and the implications for Theology in Oral Context Today.@sbts.edu. retrieved on 29 $9^{\text {th }}$ January 2017

Foster, Stuart.(2008) “Oral Theology in Lomwe songs” International Bulletin of Missionary Research 32. 
International Journal of Culture and Religious Studies

Vol.1, Issue No.1, pp 1 - 7, 2020

Www.carijournals.org

Mbiti, John. (1979)"The Biblical Basis for present trends in African Theology." Africa Theology.

Mbiti, John.(1979)"Cattle are Born with Ears their Horns Grow Later: Towards an Appreciation of African Oral Theology." Africa Theological Journal 8 (1) .

Naude,Piet(1996) "Theology with a New Voice with a New Voice, The case for an Oral Theology in the South African Context," Journal for Theology for Southern African .

Phillipart, Michael.(1992) The African church in communication Era. Nairobi, Kenya: St. Paul's Publications.

Pobee. John S.(1989) "Oral Theology and Christian Oral Tradition: Challenge to our traditional Archival Concept”. Mission studies 6 .

Salmon,Bruce.(1988) Story Telling in Preaching. Nashville. Tennesse :Broadman press.

Simmons, Antony.(2017) African Theology and Black Theology part 1. http: // black and Christian. Com/articles/academy/simmons-02-04/shm/retrieved 13 January 2017 16:07 p.m. 